\title{
Proces adaptacji rodziców do roli rodzicielskiej dziecka z zespołem Downa jako strategia radzenia sobie z sytuacją stresową
}

\begin{abstract}
Karolina Kaliszewska, Proces adaptacji rodziców do roli rodzicielskiej dziecka $z$ zespotem Downa jako strategia radzenia sobie z sytuacja stresowa [The process of adaptation to the role of a parent of a child with Down syndrome as a stress management strategy]. Interdyscyplinarne Konteksty Pedagogiki Specjalnej, nr 17, Poznań 2017. Pp. 71-31. Adam Mickiewicz University Press. ISSN 2300-391X
\end{abstract}

The process of adaptation to the role of a parent of a child with Down Syndrome is very difficult, multi-staged and stress-causing both for mothers and for fathers. Coping with the parental stress is a constant challenge for mothers and fathers of a child with Down syndrome and it increases the significance of different types of social support. The choice of coping strategy influences parents' cognitive abilities, competences of emotional and behavioural regulation and facilities more positive assessment of their intellectually disabled child. In case parents choose more adaptive, that is problem - focused coping strategy the adjustment to parental role proceed more fluent, or even more adequate. In addition, it has been proven that receiving social support and using accommodative coping style may boost the process of adaptation to parental role of a child with Down syndrome.

KEY WORDS: Down syndrome, family with disabled child, adaptation to parental role, coping with parental stress, social support 


\section{Rola rodzicielska. Wprowadzenie}

Każdy człowiek, który jest częścią systemu rodziny, przyjmuje określone zadania; przejawia określone postawy i sposób zachowania się. To przyjęta rola determinuje rodzaj aktywności, wybory, jakie powinny być dokonane i jakie są dokonywane. Analogicznie w obrębie systemu rodzinnego możemy stwierdzić, że to nadana lub przyjęta rola determinuje nasze relacje i sposób zachowania się w stosunku do pozostałych członków rodziny¹. W ciągu życia każdy człowiek przyjmuje lub wchodzi w wiele różnych ról, czego funkcją jest treść i forma aktywności². Amedeo Cencini i Alessandro Manenti ${ }^{3}$ podają, że rola społeczna to określony w danej kulturze zbiór oczekiwań kierowanych wobec jednostki zajmującej określoną pozycję w strukturze społecznej. Normy definiują role, określają zachowanie danej osoby, są przez nią interpretowane i stanowią jedyną wykładnię dla indywidualnego systemu znaczeń. Nie zawsze dana osoba od razu wchodzi w nadaną lub wybraną przez siebie rolę społeczną, często spełnienie powierzonych wymogów i oczekiwań jest wynikiem długiego procesu wchodzenia w rolę, co związane jest z indywidualnym rozwojem ${ }^{4}$. Na przykład rola rodzicielska nie zawsze jest wynikiem urodzenia dziecka, często jest kontynuacją roli związanej z płcią i pełnionej roli małżeńskiej5.

Teresa Rostowska ${ }^{6}$ uważa, że rola rodzinna najczęściej oznacza wzór zachowania (lub wyobrażeń o nich), podejmowanego w sy-

1 V. Będkowska-Heine, Tworzenie roli matki dziecka niepetnosprawnego, [w:] Wybrane zagadnienia psychopatologii rozwoju dzieci i młodzieży, red. S. Michilewicz, Oficyna Wydawnicza „Impuls”, Kraków 2003, s. 77-93.

2 M. Łoś, "Role społeczne" w nowej roli, [w:] Małe struktury społeczne, red. J. Machaj, Wydawnictwo UMCS, Lublin 1999, s. 93-106.

${ }^{3}$ A. Cencini, A. Manenti, Psychologia a formacja, Wydawnictwo WAM, Kraków 2002.

${ }^{4}$ M. Łoś, op. cit.

${ }^{5}$ M. Ziemska, Postawy rodzicielskie, Wiedza Powszechna, Warszawa 1973.

${ }^{6}$ T. Rostowska, Małżeństwo, rodzina, praca a jakość życia, Oficyna Wydawnicza „Impuls”, Kraków 2009. 
tuacjach społecznych związanych z funkcjonowaniem rodziny. Według Marii Ziemskiej rola rodzicielska to nabyta struktura poznawczo-dążeniowo-afektywna ukierunkowująca zachowanie rodziców wobec dziecka ${ }^{8}$. Role rodzicielskie posiadają pewne zachowania wspólne dla obojga rodziców oraz takie, które są specyficzne tylko dla matki czy ojca. Np. rola matki wymaga poczęcia dziecka i jego urodzenie, dbanie o jego prawidłowy rozwój, opiekę i wychowanie. Rolą matki jest też obdarzanie dzieci uczuciem, okazywanie mu serdeczności, wyrozumiałości, wprowadzanie go w życie rodzinne i tradycje 9 .

W przypadku roli ojca nastąpiły zmiany w odniesieniu do tego, jakie były oczekiwania $\mathrm{w}$ tradycyjnej, patriarchalnej rodzinie, a jakie są współcześnie. Przemiany społeczno-kulturowe, gospodarcze spowodowały, że od ojca nie oczekuje się już tylko tego, że będzie zajmował się utrzymaniem rodziny, zapewniał rodzinie stabilność ekonomiczną. W roli rodzicielskiej współczesnego mężczyzny mieszczą się takie zachowania jak uczestnictwo w pracach domowych, zajmowanie się dziećmi i wykonywanie na ich rzecz czynności opiekuńczo-wychowawczych ${ }^{10}$. Następuje stopniowe zacieranie się różnic między rolami ojca i matki, a ich funkcje coraz bardziej się uzupełniają.

Pełniąc funkcję rodzicielską, rodzice mogą zaspokajać zarówno potrzeby własne, jak i potrzeby dzieci. W obszarze potrzeb własnych miesi się: uznanie, szacunek, samorealizacja, macierzyństwo (ojcostwo), przekazywanie dzieciom wartości, wiedzy, własnych osiągnięć.

W przypadku zaspokajania potrzeb dzieci rodzice dbają o ich rozwój we wszystkich obszarach ich życia i przygotowują ich do

7 Ibidem.

${ }^{8}$ M. Ziemska, op. cit.

${ }^{9}$ T. Rostowska, op. cit.

${ }^{10}$ M. Plopa, Więzi w matżeństwie i rodziny. Metody Badań, Oficyna Wydawnicza „Impuls”, Kraków 2006; B. Harwas-Napierała, Specyfika komunikacji interpersonalnej w rodzinie ujmowanej jako system, [w:] Psychologia rodziny, red. I. Janicka, H. Liberska, Wydawnictwo Naukowe PWN, Warszawa 2014, s. 27-69. 
funkcjonowania w społeczeństwie ${ }^{11}$. Zaangażowanie w odgrywanie tej roli i właściwa jej realizacja może korzystnie wpłynąć na obraz siebie, system wartości, poczucie tożsamości osobowej i przyczynia się do satysfakcji z realizowanej roli12.

Badacze wyróżniają dwa pojęcia związane $\mathrm{z}$ terminem roli rodzicielskiej; pierwsze to "wymóg roli”, czyli oczekiwania społeczne nadane danej osobie, druga to "koncepcja roli”, czyli interpretacja tych wymogów przez daną osobę ${ }^{13}$.

\section{Rola rodzica dziecka z zespołem Downa}

Według Ziemskiej ${ }^{14}$ rodzicielstwo jest ważnym czynnikiem dającym poczucie bezpieczeństwa młodemu człowiekowi i określającym jego status w społeczeństwie. Ojciec i matka dzięki sukcesom osiąganym przez własne potomstwo niewątpliwie czują dumę i radość. Nierzadko dzieci dają rodzicom sposobność przeżywania pośrednio sukcesów, których sami nie mieli możliwości doświadczyć, innymi słowy dzieci są dla rodziców również źródłem osobistej satysfakcji ${ }^{15}$.

Inne doświadczenia mają rodzice dzieci z zespołem Downa. Jak ujawniają badania, przyjście na świat potomka z niepełnosprawnością intelektualną jest stanem trudnym, często nieoczekiwanym i nieakceptowanym ${ }^{16}$. Małgorzata Kościelska17 tłumaczy, że w większości przypadków rodzice decydujący się na posiadanie dzieci nie wyobrażają sobie siebie w roli opiekunów dziecka niepełnospraw-

11 T. Rostowska, op. cit.

12 M. Ziemska, op. cit.

${ }^{13}$ A. Cencini, A. Manenti, op. cit.

14 M. Ziemska, op. cit.

$15 \mathrm{~V}$. Będkowska-Heine, op. cit.

${ }^{16}$ M. Kościelska, Trudne macierzyństwo, Wydawnictwo Szkolne i Pedagogiczne, Warszawa 1998; H. Liberska, M. Matuszewska, Model rodziny z dzieckiem niepetnosprawnym, [w:] Rodzina z dzieckiem niepetnosprawnym - możliwości i ograniczenia rozwoju, red. H. Liberska, Difin, Warszawa 2011, s. 41-66; A. Żyta, Rodzeństwo osób z głębszą niepetnosprawnościa intelektualna, Oficyna Wydawnicza „Impuls”, Kraków 2004.

${ }_{17}$ M. Kościelska, op. cit. 
nego. Oczekują po porodzie satysfakcji płynącej z normalnego rozwoju potomka i jego osiągnięć rozwojowych. W takich przypadkach diagnoza lekarska jest zdarzeniem niezwykle obciążającym emocjonalnie, a szok związany z diagnozą wpływa na to, że niektórzy rodzicie rezygnują z zabrania chorego dziecka do domu. W chwili narodzin dziecka i diagnozy zespołu Downa rodzice doświadczają silnego uczucia depresji ${ }^{18}$.

Po jej początkowym okresie spowodowanym narodzinami i sytuacją diagnozy, samopoczucie rodziców ulega stopniowej poprawie aż do momentu, gdy dziecko osiągnie około czwarty miesiąca życia. W tym czasie pojawia się druga fala depresji spowodowana tym, że rodzice obserwują następstwa rozwojowe związane z zespołem Downa. Zaczynają dostrzegać, że ich niemowlę słabiej reaguje na bodźce z otoczenia i rzadziej się uśmiecha niż dzieci rozwijające się prawidłowo. Kilka fal depresji może również wystąpić w okresie przedszkolnym, gdy rodzice zaczynają dostrzegać trudności rozwojowe w zakresie chodzenia, mówienia, korzystania $\mathrm{z}$ toalety, a przede wszystkim w nauce szkolnej. Ponowne doświadczenie depresji może pojawić się u rodziców w okresie dojrzewania ich dzieci oraz w początkach okresu ich dorosłości. Silne reakcje emocjonalne okazują się być stałym elementem wychowywania dziecka z zespołem Downa we wszystkich okresach jego rozwoju ${ }^{19}$.

\section{Stres związany z otrzymaniem diagnozy o niepełnosprawności dziecka}

Konsekwencje psychologiczne dla rodziców związane z przesiewowymi badaniami prenatalnymi oraz reakcje emocjonalne po-

18 R.N. Emde, C. Brown, Adaptation to the birth of a Down's syndrome infant: Grieving and maternal attachment, "Journal of the American Academy of Child Psychiatry" 1978, nr 17, s. 299-323; C. Zahn-Waxler, S. Duggal, R. Gruber, Parental psychopathology, [w:] Handbook of parenting 2, 3, red. M.H. Bornstein, Mahwah, Lawrence Erlbaum Associates, Mahwah 2002, s. 295-327.

${ }^{19}$ C. Zahn-Waxler, S. Duggal" R. Gruber, op. cit. 
wstające $\mathrm{u}$ tych rodziców, którzy po raz pierwszy usłyszeli diagnozę o niepełnosprawności ich potomka, dobrze ilustrują eksploracje przeprowadzone przez Sue Hall, Martina Bobrow i Theresę M. Marteau ${ }^{20}$. Badacze prowadzili analizy $w$ trzech podgrupach rodziców dzieci z zespołem Downa. Te trzy grupy to osoby: a) które otrzymały fałszywy, negatywny wynik badań prenatalnych, b) którym nie zaproponowano badań przesiewowych, oraz osoby c) które odmówiły wykonania testu. W wyniku przeprowadzonych badań Hall, Bobrow i Marteau ustalili, że największe nasilenie negatywnych emocji występuje u rodziców, którzy otrzymali nieprawidłowy wynik prenatalnego badania przesiewowego, to znaczy byli informowani o braku dysfunkcji rozwojowych u dziecka. Fałszywie ujemny wynik w omawianych badaniach był pozytywnie skorelowany z wyższym stresem rodzicielskim, silniejszą skłonnością do obwiniania innych za narodziny dziecka oraz bardziej negatywną postawą wobec niego w porównaniu z rodzicami, którzy odmówili wykonania badania. Inne zachowania natomiast przejawiali rodzice, którzy otrzymali właściwą diagnozę prenatalną, Jak wskazują Hall, Bobrow i Marteau, rodzice, którzy wiedzieli, że płód ma cechy zespołu Downa, ale zdecydowali się kontynuować ciążę, wykazali się niższym poziomem niepokoju, bardziej pozytywnymi reakcjami i akceptującą postawą wobec dziecka21. Podobne wyniki uzyskał też w swoich badaniach Brian Skotko ${ }^{22}$. Autor uważa, że pozytywny stan emocjonalny rodziców (szczególnie matek), którzy wiedzą, że urodzi im się dziecko z zespołem Downa, wynika ze stopniowego pogodzenia się i oswojenia $\mathrm{z}$ nienormatywną sytuacją²3. Skotko zauważył też, że kobiety, które zdecydowały się kontynuować ciążę po diagnozie prenatalnej zespołu Downa, uczyniły tak przede

20 S. Hall, M. Bobrow, T.M. Marteau, Psychological consequences for parents of false negative results on prenatal screening for Down's syndrome: Retrospective interview study, “British Medical Journal” 2000, nr 320, s. 407-412.

21 S. Hall, M. Bobrow, T.M. Marteau, op. cit.

22 B. Skotko, Mothers of children with down syndrome reflect on their postnatal support, "Pediatrics" 2005, nr 115, s. 64-77.

23 Ibidem. 
wszystkim ze względu na osobiste przekonania i wartości. Większość z tych matek, decydując się na badania przesiewowe, podjęło już decyzję, że będą kontynuować ciążę bez względu na otrzymany wynik. Natomiast kobiety, które otrzymały informację, że ich dziecko będzie miało zespół Downa, ale nie podjęły jeszcze decyzji o kontynuacji ciąży, chciały zebrać więcej informacji. Co więcej, większość z tych matek wykazało frustrację podczas interakcji z lekarzami i podkreślało potrzebę zapoznania się z aktualniejszymi materiałami naukowymi na temat zespołu Downa oraz prosiły o skierowanie do lokalnych grup wsparcia ${ }^{24}$.

\section{Proces przystosowanie się do roli rodzica dziecka z zespołem Downa}

Analizując role rodziców dzieci z niepełnosprawnością intelektualną, nie można powiedzieć jedynie o wejściu w rolę lub o przyjęciu swojej roli lecz bardziej dokładnym stwierdzeniem jest mówienie o procesie przystosowania się do roli. W ujęciu Violetty Będkowskiej-Heine ${ }^{25}$ proces przystosowania się do roli rodzica dziecka $\mathrm{z}$ niepełnosprawnością obejmuje następujące etapy: wpadnięcie $\mathrm{w}$ pułapkę roli, oswajanie się z rolą, identyfikacja $\mathrm{z}$ rolą, wdrukowanie $\mathrm{w}$ rolę, wzrastanie $\mathrm{w}$ rolę, autonomizacja roli, fetyszyzacja roli, negacja roli oraz kreacja roli.

Etap pierwszy „wpadnięcie w pułapkę roli” obejmuje fazę szoku i konfrontacji z diagnozą dotyczącą niepełnosprawności dziecka. W tym etapie następuje szereg negatywnych doznań psychoemocjonalnych, takich jak lęk, zagubienie, chaos, dezorientacja, a także gniew $i$ agresja. Destabilizacji ulega również system rodziny, a młodzi rodzice doświadczają kryzysu ${ }^{26}$. Na tym poziomie rodzice nie widzą pozytywnych stron swojego rodzicielstwa.

${ }^{24}$ Ibidem.

25 V. Będkowska-Heine, op. cit.

${ }^{26}$ M. Kościelska, Oblicza upośledzenia, Wydawnictwo Naukowe PWN, Warszawa 1995; M. Kościelska, Trudne macierzyństwo...; M. Ziemska, op. cit. 
W kolejnym etapie rodzice podejmują próbę wyjścia z kryzysu poprzez „oswajanie się z rolą". Gdy rodzice uzyskują pewność, że niepełnosprawność dziecka jest nieodwracalna i niewyleczalna, podejmują próby radzenia sobie z kryzysem poprzez stosowanie różnych mechanizmów obronnych, takich jak: zaprzeczenie, racjonalizacja czy wyparcie. Na tym etapie rodzice nie odczuwają radości z odgrywania swojej roli i nie widzą też pozytywnych stron trudnego rodzicielstwa, jednak jeżeli nie nastąpiło odrzucenie dziecka, podejmują oni wszelkie działania związane z opieką nad ich potomkiem, wychowaniem oraz rehabilitacją.

Z biegiem czasu następuje „identyfikacja z rolą”, czyli wczucie się w rolę na etapie zadaniowym. Rodzice nabierają doświadczenia i kompetencji rodzicielskich. Dzięki coraz bardziej sprawnemu wykonywaniu czynności rodzicielskich matki jak i ojcowie mają większą pewność i silniejsze poczucie zaufania do swoich kompetencji. Powoli rodzice tworzą wspólną przestrzeń z dzieckiem.

Na etapie „wdrukowania roli” następuje świadome przyswajanie, poszukiwanie i realizowanie sposobów wychowywania dziecka niepełnosprawnego intelektualnie, tworzenie się tożsamości rodzicielskiej. Matka i ojciec poszukują, uczą się i wdrażają wybrane sposoby i metody wychowywania dziecka. W tym okresie dla rodziców bardziej istotne jest dbanie o szczęście i spokój niepełnosprawnych dzieci niż wspieranie ich rozwoju.

Gdy codzienność jest niezmienna i przewidywalna, a zadania i role rodziców jasno określone następuje okres „wrastania w rolę”. Następuje generalizacja tożsamości rodzicielskiej i brak poczucia wyobcowania. Rodzice dziecka z niepełnosprawnością intelektualną nie spostrzegają już siebie jako stygmatyzowanych i gorszych. Dziecko staje się członkiem systemu rodzinnego i częścią psychicznej struktury rodzica.

Do „autonomizacji roli” dochodzi gdy opieka rodzicielska przynosi matce i ojcu satysfakcję oraz jest przez nich spostrzegana jako istotna wartość w ich życiu. Rodzice realnie rozpoznają szanse rozwojowe swoich dzieci, stają się też źródłem informacji i wsparcia dla innych młodych rodziców dzieci z niepełnosprawnością intelek- 
tualną. Korzystają śmiało z pomocy specjalistycznej bez poczucia winy czy zażenowania. Etap ten jest konsekwencją akceptacji swojej roli rodzicielskiej oraz dużej świadomości swojego dziecka. Dopiero przy dobrej adaptacji do roli rodzica dziecka z niepełnosprawnością intelektualną można zaobserwować, że zarówno ojcowie, jak i matki oprócz wypełniania obowiązków opiekunczych i wychowawczych w stosunku do swoich dzieci przyjmują również wobec nich postawę terapeutyczną.

Będkowska-Heine ${ }^{27}$ wymienia dodatkowe cztery typy ról rodzicielskich, które są przejawem nieprzystosowania się matki i ojca dziecka z niepełnosprawnością intelektualną do roli rodzica, tymi rolami są: fetyszyzacja roli, manipulacja rolą, negacja roli oraz kreacja roli. „Fetyszyzacja roli” oznacza, że rodzice poświęcają całą swoją uwagę i wszystkie swoje działania roli rodzica. W opinii badaczki takie zachowania przejawiane są często przez matki, które nie dopuszczają nikogo do opieki nad dzieckiem ${ }^{28}$. Potrzeby własne są dostosowywane do potrzeb dziecka i rezygnuje się zupełnie z prywatnego życia czy czasu dla siebie. Rozwój autonomii i samodzielności dziecka wiąże się z lękiem i sprzeciwem opiekuna. "Manipulacja rolą" występuje wtedy, gdy rola rodzica dziecka z niepełnosprawnością służy jako narzędzie do uzyskania korzyści materialnych czy społecznych. „Negacja roli” jest natomiast wtedy, gdy następuje odrzucenie dziecka niepełnosprawnego, rodzic nie zgadza się na sprawowanie opieki nad dzieckiem i zaprzecza swojemu rodzicielstwu. „Kreacja roli” ma miejsce w przypadku kompulsywnego wypełniania innych pozostałych ról, które nie są potrzebne ani też wymagane przez otoczenie zewnętrzne. Swoistym wyrazem „kreacji roli” może być np. decyzja o samotnym rodzicielstwie.

Inny proces przystosowania się do roli rodzicielskiej prezentuje Kościelska, korzystając z wyników badań przeprowadzonych w 1993 r. przez Annę Krawczyk29. Badania przeprowadzone przez

\footnotetext{
27 V. Będkowska-Heine, op. cit.

${ }^{28}$ Ibidem,

${ }^{29}$ M. Kościelska, Trudne macierzyństwo...
} 
Krawczyk obejmowały badanie młodych matek dzieci z niepełnosprawnością $\mathrm{w}$ okresie do trzech miesięcy po porodzie ${ }^{30}$. Badane kobiety były w podobnym wieku (średnia wieku to 26 lat) i miały podobną sytuację materialną oraz rodzinną, tj. wszystkie kobiety żyły z ojcami dziecka, miały zapewnione warunki mieszkaniowe i wykształcenie co najmniej średnie. Krawczyk kontaktowała się z matkami trzykrotnie. Celem spotkań było przeprowadzenie wywiadu z kobietami, dzięki któremu można było uzyskać takie informacje jak: a) stopień satysfakcji płynącej z macierzyństwa, b) poczucie kompetencji w pełnieniu nowych obowiązków, c) emocje w kontakcie z dzieckiem, d) posiadany przez matkę obraz dziecka, e) funkcjonowanie dziecka, f) czas poświęcony dziecku przez matkę i sposób jego wykorzystania, g) posiadany przez matkę obraz zmian w życiu rodziny. Na podstawie uzyskanych narracji wyróżniono trzy grupy matek ze względu na ich stopień przystosowania się do swojej roli macierzyńskiej: a) matki dobrze przystosowane do roli rodzicielskiej, b) matki z trudem adaptujące się do roli rodzicielskiej, c) matki źle zaadoptowane do roli rodzicielskiej.

Kościelska ${ }^{31}$ podaje, że matki bardzo dobrze przystosowane do macierzyństwa posiadają dużą satysfakcję z odgrywanej roli rodzicielskiej. Kobiety te czuły radość i dumę z samego faktu stania się matką, kontakt z dzieckiem był pozytywny, poświęcały noworodkom dużo czasu, okazywały ciepło i pozytywne emocje. Dzieci również uspokajały się, kiedy matki były obok. Zarówno matki, jak i dzieci szybko uczyły się siebie nawzajem, co w konsekwencji dawało początki rozwoju obustronnie pozytywnej, silnej więzi opartej na poczuciu bezpieczeństwa, ciepła, wzajemnego zrozumienia i radości ze wspólnie spędzanego czasu. Kobiety te wykazywały wysoki poziom kompetencji macierzyńskiej, nie uskarżały się na nadmiar obowiązków czy brak wsparcia ze strony pozostałych członków rodziny. Dzięki dobremu przystosowaniu się kobiet do roli macierzyńskiej również ojcowie dzieci mieli sposobność rozwoju swoich

\footnotetext{
${ }^{30}$ Ibidem.

31 Ibidem.
} 
rodzicielskich kompetencji. Partnerzy dobrze przystosowanych matek dzieci z niepełnosprawnością intelektualną wskazywali na rozwój własnej roli jako opiekuna, ojca oraz współmałżonka.

Z kolei matki, które wykazywały trudności w procesie adaptacji do macierzyństwa, zdaniem Kościelskiej wskazywały na duże poczucie satysfakcji z faktu stania się matką, jednakże trudności zaczęły pojawiać się podczas nauki opieki nad dzieckiem.

Kobiety te mówiły o problemach z pielęgnacją dziecka, uregulowaniem rytmu snu i czuwania, braku czasu dla siebie i nadmiaru obowiązków, którym nie były w stanie same sprostać. Ponadto matki te sygnalizowały dolegliwości fizyczne i dopiero z biegiem czasu nabywały kompetencji rodzicielskich i poczucia skuteczności. Również sfera emocjonalna matek zaczęła ewoluować. Po porodzie kobiety zaczęły odczuwać mieszankę uczuć takich jak radość, entuzjazm i szczęście, jednocześnie ogarniał ich lęk przed brakiem posiadanych kompetencji i obawa przed skrzywdzeniem dziecka. Obraz dziecka był wśród tych kobiet zróżnicowany. Z jednej strony matki te widziały $\mathrm{w}$ dzieciach źródło swojej radości i miłości, a z drugiej strony powód ich zmęczenia, rozdrażnienia i frustracji. Dzieci matek częściowo dobrze przystosowanych nie miały uregulowanych pór spania i jedzenia, dużo płakały i miały zaburzenia trawienne. Należy podkreślić, że partnerzy tych kobiet pracowali, a wszelkie prace i obowiązki domowe przejmowały kobiety. Mówiły one o poczuciu izolacji, odosobnienia i chęci rozpoczęcia pracy zarobkowej.

Trzecią grupę wyróżnioną przez Kościelską ${ }^{32}$ stanowiły kobiety źle przystosowane do swojej roli rodzicielskiej. Badane wskazywały na niskie poczucie satysfakcji z odgrywanej roli. Uskarżały się na liczne dolegliwości somatyczne, cierpiały z powodu przemęczenia, braku snu i ogólnego złego samopoczucia. Wszystkie badane wyrażały chęć szybkiego powrotu do pracy zarobkowej. Posiadały niskie kompetencje rodzicielskie i potrzebowały dużej pomocy i wsparcia ze strony rodziny. Stan emocjonalny badanych kobiet był słaby,

\footnotetext{
32 Ibidem.
} 
matki wskazywały na przewagę negatywnych emocji nad pozytywnymi, spostrzegany przez nich obraz dzieci był negatywny. Mianowicie dzieci w ich oczach były uciążliwe, marudne, płaczące i niezmiernie absorbujące ich czas i energię. Funkcjonowanie dzieci również było zaburzone, noworodki, mało i krótko spały, rodzice poświęcały im mało czasu i skupiały się wyłącznie na zabiegach pielęgnacyjnych.

\section{Zmiana perspektywy oceny wpływu niepełnosprawności dziecka na system rodziny}

W ciągu ostatnich 40 lat sposób myślenia badaczy o procesie adaptacji do roli rodzica dziecka z zespołem Downa jako o procesie patologicznym i sytuacji kryzysowej ${ }^{33}$ został zastąpiony perspektywą myślenia $\mathrm{w}$ kategoriach stresu i umiejętności radzenia sobie $\mathrm{z}$ trudnościami związanymi $\mathrm{z}$ nietypowym rodzicielstwem ${ }^{34}$. Ta zmiana może wynikać z potrzeby oddalenia się od redukcjonistycznego, zorientowanego na problem podejścia ${ }^{35}$.

Przegląd badań z obszaru rodziny z dzieckiem niepełnosprawnym intelektualnie sprzed lat 80 . XX w. wykazuje, że pojawienie się dziecka z niepełnosprawnością intelektualną może mieć negatywny wpływ na funkcjonowanie i dobre samopoczucie rodziców, jak również na rozmaite aspekty rodzinnej atmosfery i jej funkcjonowania ${ }^{36}$.

${ }^{33}$ J. Blacher, C.L. Neece, E. Paczkowski, Families and intellectual disability, "Current Opinion in Psychiatry" 2005, nr 18(5).

${ }^{34}$ B.H. Abery, Focus on Exceptional Children, "Family Adjustment and Adaptation with Children with Down Syndrome" 2006, nr 38(6), s. 1-18; M. Van Riper, A change of plans: the birth of a child with down syndrome doesn't have to be a negative experience, "American Journal of Nursing" 2003, nr 103, s. 71-74.

${ }^{35}$ G.E. Richardson, The metatheory of resilience and resiliency, "Journal of Clinical Psychology" 2002, nr 58, s. 307-321.

${ }^{36}$ R.M. Hodapp, L.A. Ricci, Fathers of children with down's syndrome versus other types of intellectual disability: Perceptions, stress and involvement, "Journal of Intellectual Disability Research" 2003, nr 47, s. 273-284. 
Pierwsze przeprowadzone na ten temat analizy badawcze wykazały, że u matek dzieci z niepełnosprawnością intelektualną łatwo można zauważyć większą depresję i większe trudności w kontrolowaniu gniewu wobec swoich dzieci w porównaniu do matek dzieci rozwijających się prawidłowo ${ }^{37}$. Podobnie ojcowie dzieci z niepełnosprawnością intelektualną wykazywali większy poziom depresji i neurotyczności, jak również niższy poziom dominacji, poczucia własnej wartości i radości z posiadania dzieci z niepełnosprawnością intelektualną $\mathrm{w}$ stosunku do ojców dzieci rozwijających się prawidłowo ${ }^{38}$. W omawianych badaniach rodziny z dziećmi z niepełnosprawnością intelektualną charakteryzowały się niżniższym poziomem satysfakcji małżeńskiej, a także zwiększonym poziomem konfliktów małżeńskich i rozwodów ${ }^{39}$. W tych rodzinach matki zazwyczaj mocno angażowały się w opiekę nad dziećmi z niepełnosprawnością intelektualną, podczas gdy ojcowie stawali się bardziej wycofani zarówno emocjonalnie, jak i fizycznie ${ }^{40}$.

Od 1980 r. naukowcy zmieniają podejście uwzględniające dziecko z niepełnosprawnością, jako przyczynę psychopatologii, wprowadzając koncepcję czynników stresujących w obrębie rodziny $\mathrm{z}$ dzieckiem niepełnosprawnym ${ }^{41}$. Zgodnie $\mathrm{z}$ tą zmianą perspektywy czynniki stresujące w systemie rodzinnym mogą prowadzić do negatywnych skutków rodzicielskich, takich jak złe samopoczucie, większy poziom depresyjności ${ }^{42}$ czy negatywny obraz dziecka ${ }^{43}$.

37 S. Cummings, H. Bayley, H. Rie, Effects of the child's deficiency on the mother: A study of mentally retarded, chronically ill, and neurotic children, "American Journal of Orthopsychiatry" 1966, nr 36, s. 595-608; W.N. Friedrich, W.L. Friedrich, Psychological assets of parents of handicapped and nonhandicapped children, "American Journal of Mental Deficiency" 1981, nr 85, s. 551-553.

38 W.N. Friedrich, W.L. Friedrich, op. cit.

39 S. Cummings, H. Bayley, H. Rie, op. cit.; W.N. Friedrich, W.L. Friedrich, op. cit.

${ }^{40}$ P. Beckman-Bell, Topics in Early Childhood Special Education, "Child - related stress in families of handicapped children" 1981, nr 1(3), s. 45-54.

${ }^{41}$ R.M. Hodapp, L.A. Ricci, op. cit.

42 W.N. Friedrich, W.L. Friedrich, op. cit.

${ }^{43}$ M. Kościelska, Trudne macierzyństwo... 
Jednocześnie nowa perspektywa badań pozwoliła dostrzec, że niepełnosprawność dziecka może również wzmacniać rodziców. Dostrzeżono bowiem, że w wyniku doświadczania sytuacji niepełnosprawności u rodziców może nastąpić wzmocnienie cech osobistych, może też dojść do wzmocnienia całego systemu rodzinnego i pojawienia się wysokiego poziomu spójności rodziny ${ }^{44}$.

\section{Umiejętności radzenia sobie z problemami przez rodziców dzieci z zespołem Downa}

Przegląd literatury z zakresu strategii radzenia sobie ze stresem rodzicielskim (ang. family stress coping strategies) wśród rodzin dzieci $\mathrm{z}$ niepełnosprawnością intelektualną $\mathrm{w}$ porównaniu do rodzin $\mathrm{z}$ dzieckiem rozwijającym się prawidłowo ukazuje, że w rodzinach wychowujących dzieci z niepełnosprawnością istnieje wyższy poziom stresu i niepokoju ${ }^{45}$. Dysproporcje pomiędzy obiema grupami rodzin dobrze ilustruje badanie dotyczące poziomu stresu rodzicielskiego w dopasowanych pod względem społeczno-ekonomicznych grupach badawczych ${ }^{46}$. W tym porównaniu zaobserwowano, że rodzice dzieci z zespołem Downa zgłaszają większe trudności opiekuncze, większe nasilenie stresu związanego z wychowywaniem dziecka (uciążliwość wykonywanych zadań, brak akceptacji dla

${ }^{44}$ J.S. Greenberg, M. Wyngaarden-Krauss, M. Mailick-Seltzer, R. Chou, J. Hong. The effect of quality of the relationship between mothers and adult children with schizophrenia, autism, or Down syndrome on maternal well-being: the mediating role of optimis, "American Journal of Orthopsychiatry" 2004, nr 74(1), s. 14-25; R.M. Hodapp, Families of persons with down syndrome: New perspectives, findings, and research and service needs, "Developmental Disabilities Research Reviews" 2007, nr 13(3), s. 279-287.

${ }^{45}$ E. Leinonen, M. Itälinna, T. Saloviita, Explaining the parental stress of fathers and mothers caring for a child with intellectual disability: A Double ABCX model, "Journal of Intellectual Disability Research" 2003, nr 47, s. 300-312.

${ }^{46}$ M. Roach, G.I. Orsmond, M.S. Barratt, Mothers and fathers of children with Down syndrome: Parental stress and involvement in childcare, "American Journal on Mental Retardation" 1999, nr 104, s. 422-436. 
prac związanych z opieką nad niepełnosprawnym dzieckiem) oraz stresu związanego z rodzicielstwem (niekompetencja, depresja, problemy zdrowotne, osłabienie roli rodzicielskiej i roli małżeńskiej) niż rodzice dzieci rozwijających się prawidłowo. Dla obu grup rodziców stres matczyny związany był z trudnościami opiekuńczymi, natomiast stres ojcowski wynikał z samej obecności dziecka z zespołem Downa. Matki, które wykazywały większe zaangażowanie w opiekę nad dziećmi, doświadczały więcej komplikacji zdrowotnych, mniejszego wsparcia ze strony współmałżonka i większych trudności w wypełnianiu roli małżeńskiej. Ojcowie, którzy wykazywali większe zaangażowanie w opiekę nad dzieckiem, doświadczali mniejszych trudności w sprawach dotyczących kompetencji rodzicielskiej. Badanym rodzicom towarzyszył również niepokój w związku z ograniczonym czasem na wypoczynek, co powodowało obniżenie aktywności rekreacyjnej oraz zwiększenie potrzeby planowania wypoczynku. Przy czym trzeba podkreślić, iż w badaniu poziomu zadowolenia rodziców ze sposobu dysponowania swoim czasem, rodzice dzieci z zespołem Downa częściej zauważali potencjalne korzyści wynikające ze wspólnego spędzania czasu wolnego z dziećmi czy całą rodziną ${ }^{47}$.

Zróżnicowania źródeł stresu rodziców dokonał Richard R. Abidin ${ }^{48}$. Autor wyróżnił dwa typy stresu. Pierwszy określił jako stres rodzicielski pojawiający się u każdego rodzica, a odnoszący się do zachowań dzieci, które przysparzają rodzicom trudności. Drugi typ to stres związany $\mathrm{z}$ wychowywaniem dziecka $\mathrm{z}$ niepełnosprawnością intelektualną. Tutaj źródłem stresu mogą być m.in.: diagnoza niepełnosprawności dziecka, zachowanie nieprzystosowawcze potomka, jego specyficzne trudności rozwojowe czy dodatkowe komplikacje zdrowotne ${ }^{49}$. Brian Abery uważa, że wymienione zarówno w pierwszym, jak i drugim typie stresu zmienne odnoszą się mię-

${ }^{47}$ D.O.M. Wayne, S. Krishnagiri, Parents' leisure: The impact of raising a child with down syndrome, “Occupational Therapy International” 2005, nr 12(3), s. 180-194.

48 R. Abidin, Parenting stress index manual. Odessa: Psychological Assessment Resources 1995.

49 R. Abidin, op. cit. 
dzy innymi do poczucia własnej skuteczności rodzica, zaufania w profesjonalną pomoc, poczucia kompetencji oraz przekonań, wartości i oczekiwań rodziców ${ }^{50}$. Oba wymienione typy stresu zdaniem Garego Petersona i Charlesa B. Hennona powodują wzrost napięcia w systemie rodzinnym, ponadto wprowadzają niestabilność emocjonalną i nadmierną sztywność w zachowaniu członków rodziny ${ }^{51}$. Wspominając o niestabilności emocjonalnej w rodzinie, należy zauważyć, że jest ona szczególnie duża w rodzinach z małymi dziećmi z zespołem Downa. W tych to bowiem rodzinach, jak zauważają Hanna Liberska i Mirosława Matuszewska, występuje chroniczne doświadczanie stresu ${ }^{52}$. A taka sytuacja może się przyczyniać do izolacji społecznej lub ciężkiej depresji ${ }^{53}$. Stres rodzicielski w rodzinach $\mathrm{z}$ małymi dziećmi wydaje się wynikać m.in. z zależności pomiędzy zwiększonymi potrzebami opiekunczymi dziecka z opóźnionym lub nieprawidłowym rozwojem a poziomem kompetencji rodzicielskich oraz poziomem akceptacji niepełnosprawności dziecka ${ }^{54}$. Niskie poczucie kompetencji, niedostateczna adaptacja do roli rodzica oraz przekonanie o negatywnym znaczeniu sytuacji, w jakiej znaleźli się rodzice, zdaniem Timo Saloviity i współpracowników, jest najważniejszym wskaźnikiem stresu rodzicielskiego wśród rodziców dzieci z zespołem Downa55. Dodatkowo należy podkreślić, że sposób definiowania pełnionej przez siebie roli rodzica dziecka z niepełnosprawnością często różnicuje matki i ojców. Dla matek negatywny aspekt macierzyństwa związany jest z problemami behawioralnymi dziecka,

50 B.H. Abery, op. cit.

${ }^{51}$ G.W. Peterson, C.B. Hennon, Conceptualizing prenatal stress with family stress theory, [w:] Families and change, red. P.C. McKenry, S.J. Price; Thousand Oak, California 2005, s. 25-49.

52 H. Liberska, M. Matuszewska, op. cit.

53 P. Beckman-Bell, Topics in Early Childhood Special Education, "Child - related stress in families of handicapped children" 1981, nr 1(3), s. 45-54; D. Keller, A.S. Honig, Maternal and Paternal Stress in Families with School-Aged Children with Disabilities, "American Journal of Orthopsychiatry" 2004, nr 74(3), s. 337-348.

${ }^{54}$ E. Leinonen, M. Itälinna, T. Saloviita, op. cit.

55 Ibidem. 
podczas gdy dla ojców wiąże się on z doświadczeniem społecznego braku akceptacji dziecka ${ }^{56}$.

Badania nad stresem rodzicielskim wskazują też, że stres związany z procesem adaptacji matki i ojca dziecka z niepełnosprawnością intelektualną do roli rodzicielskiej nie dotyczy jedynie ich samych, ale może mieć również duży wpływ na samopoczucie i rozwój emocjonalno-społeczny ich niepełnosprawnych dzieci. Kościelska opisuje tę zależność jako mechanizm obustronnego oddziaływania na siebie matki i dziecka. W prowadzonych przez siebie obserwacjach wypełniania przez matki obowiązków wychowawczych i opiekuńczych w stosunku do swoich niepełnosprawnych intelektualnie dzieci, badaczka zauważyła, że stopień przystosowania się do roli rodzicielskiej matek w znaczącej mierze wpływał na poziom funkcjonowania ich dzieci ${ }^{57}$.

Podobne wnioski odnajdujemy w interpretacjach Hanny Liberskiej i Mirosławy Matuszewskiej58. Według badaczek pojawienie się dziecka niepełnosprawnego powoduje w mniejszym lub większym stopniu dezorganizację rodziny i sprzyja utracie stabilizacji $\mathrm{w}$ istniejącym już systemie funkcjonowania rodziny. Widoczne jest to w podstawowych sferach życia takich jak: emocjonalna, społeczna, aksjologiczna i ekonomiczna ${ }^{59}$. Ponadto pojawienie się dziecka z niepełnosprawnością i spowodowanie przez ten fakt naruszenia dotychczasowej równowagi istniejącej w systemie może skutkować utratą poczucia bezpieczeństwa wśród pozostałych członków rodziny60.

Osiągniecie poczucia równowagi emocjonalnej i powiązanej z nią stabilności systemu rodzinnego możliwe jest dopiero przy pełnym przystosowaniu się emocjonalnym do roli rodzica dziecka $\mathrm{z}$ niepełnosprawnością ${ }^{61}$.

56 E. Leinonen, M. Itälinna, T. Saloviita, op. cit.

${ }^{57}$ M. Kościelska, Trudne macierzyństwo..., s. 68.

58 H. Liberska, M. Matuszewska, op. cit.

${ }^{59}$ Ibidem.

${ }^{60}$ M. Kulik, W. Otrębski, Sytuacja rodzinna z dzieckiem niepetnosprawnym w wyniku choroby genetycznej, [w:] Rodzina z dzieckiem niepetnosprawnym - możliwości i ograniczenia rozwoju, red. H. Liberska Wydawnictwo Difin, Warszawa 2011.

${ }^{61}$ H. Liberska, M. Matuszewska, op. cit. 


\section{Strategie radzenia sobie $z$ problemami przez rodziców dzieci z zespołem Downa}

Istnieje powszechna zgoda co do tego, że sposób, w jaki rodzice radzą sobie z problemami wywołanymi przez niepełnosprawność intelektualną swojego potomka, przyczynia się do poprawy ich zdolności poznawczych, kontroli emocjonalnej i zachowania62. Jednak tylko w niewielu badaniach wnikliwie sprawdzano strategie radzenia sobie $\mathrm{z}$ problemami wśród rodzin osób z zespołem Downa. Radzenie sobie $z$ problemami zostało zdefiniowane jako myśli i zachowania wykorzystywane do zarządzania wymaganiami wewnętrznymi i zewnętrznymi w celu radzenia sobie $\mathrm{z}$ sytuacjami stresowymi63. Zidentyfikowano dwa typy strategii radzenia sobie ze stresem. Pierwsza strategia, zorientowanie na problem, odnosi się do wysiłków zmierzających do radzenia sobie ze źródłami stresu poprzez zmianę zachowań poszczególnych osób, zmianę warunków środowiskowych lub wykorzystując oba powyższe sposoby. Drugi typ strategii to regulacja emocjonalna, która odnosi się do wysiłków zmierzających do ograniczenia wyczerpania emocjonalnego i utrzymania zadowalającego stanu wewnętrznego ${ }^{64}$. Te typy reakcji radzenia sobie ze stresem są ze sobą powiązane, uzupełniają się i są ściśle związane z reakcjami emocjonalnymi. Ogólnie rzecz biorąc, rodzice wykazywali lepsze samopoczucie (czyli niższy poziom depresji i objawów psychosomatycznych, wyższe poziom samodzielności i samoakceptacji), jeśli tylko używali strategii akomodacyjnej podczas walki ze stresem ${ }^{65}$.

${ }^{62}$ A.P. Turnbull, J.M. Patterson, S.K. Behr, D.L. Murphy, J.G. Marquis, M.J. BlueBanning, Cognitive doping, families and disability, Paul H. Brookes Publishing Co., Baltimore 1993.

${ }^{63}$ S. Folkman, J.T. Moskowitz, Coping: pitfalls and promise, "Annual Review of Psychology" 2004, nr 55, s. 745-774.

64 S. Folkman, R.S. Lazarus, Coping as a mediator of emotion, "Journal of Personality and Social Psychology" 1988, nr 54, s. 466-475.

65 Ibidem. 
W nielicznych badaniach międzykulturowych, które dotyczyły sposobów walki ze stresem rodzicielskim wśród rodziców dzieci z zespołem Downa, odnotowano podobne wyniki do ujawnionych wczesnych rezultatów badan. Np. Lai-Wah Lam i Ann E. Macken$z^{2}{ }^{66}$ omówili przypadki chińskich matek wychowujących dzieci z zespołem Downa. Zgodnie z ich wynikami ta grupa matek częściej stosowała strategie radzenia sobie ze stresem charakteryzujące się wysokim poziomem unikania czynników stresogennych oraz poszukiwania wsparcia społecznego. Przeprowadzone przez Anthony'ego Sullivana porównania pomiędzy ojcami i matkami dzieci $\mathrm{z}$ zespołem Downa ujawniły kilka różnic między płciami w rodzicielskich strategiach walki ze stresem. W poszukiwaniu wsparcia emocjonalnego i społecznego, opanowaniu emocji i ich ekspresji oraz ograniczeniu konkurujących ze sobą czynności kobiety uzyskały wyraźnie wyższy wynik niż mężczyźni ${ }^{67}$.

W innym badaniu związku między stylem poznawczym walki ze stresem matek (akceptacja - unikanie czynników stresogennych), stanem uczuciowym oraz wrażliwością, uczestniczyło 56 matek i ich dzieci z zespołem Downa, które następnie obserwowano przez dwa lata ${ }^{68}$. Podczas walki ze stresem wykorzystywano procesy poznawcze i regulację zaburzeń afektywnych, a wrażliwość została oceniona na podstawie obserwacji relacji matka - dziecko. Wyniki wykazały, że przystępność i unikanie czynników stresogennych były stabilne $\mathrm{w}$ okresie dwóch lat. Te zmienne walki ze stresem przekładają się na cierpienia rodziców dzieci z zespołem Downa w złożony sposób. Matki z silną tendencją do reagowania na czynniki stresogenne zgłaszały większe zaburzenia afektywne niż matki, które przyjęły mniej wrażliwy sposób walki ze stresem. W tym sa-

${ }^{66}$ L. Lam, A.L. MacKenzie, Coping with a Child with Down Syndrome: The Experiences of Mothers in Hong Kong, "Qualitative Health Research" 2002, nr 12(2), s. 223-237.

${ }^{67}$ A. Sullivan, Gender differences in coping strategies of parents of children with Down syndrome, "Down Syndrome Researches and Practice" 2002, nr 8 (2), s. 67-73.

${ }^{68}$ L. Atkinson, T. Bowman, H.L. Minton, B.S. Scott, Psychological distress of parents of infants with down syndrome, "American Journal on Mental Retardation" 1997, nr 102(2), s. 161-171. 
mym czasie, unikanie poznawcze czynników stresowych i zaburzenia afektywne zmniejszyły wrażliwość behawioralną matek wobec własnych dzieci69.

\section{Wsparcie społeczne $\mathbf{i}$ jego znaczenie w radzeniu sobie ze stresem rodzicielskim $w$ rodzinach z dzieckiem niepełnosprawnym intelektualnie}

Jak zostało wcześniej wspomniane, proces adaptacji do roli rodzica dziecka z niepełnosprawnością intelektualną jest trudny i wiąże się z dużym stresem zarówno dla matki, jak i dla ojca. Ciągłe wyzwania jakie niesie ze sobą walka ze stresem rodzicielskim u matek i ojców zwiększa znaczenie dostępnych możliwości wsparcia społecznego. Korzystanie ze wsparcia społecznego rozwija u rodzica dziecka z niepełnosprawnością intelektualną poczucie, że jest pod opieką, że należy do społeczności z podobnymi problemami oraz że jej lub jego doświadczenia mogą być cenne i przydatne dla innych ${ }^{70}$.

Jak pisze Helena Sęk, żeby właściwe zrozumieć termin wsparcie społeczne, należy zasadniczo odnieść się do wiedzy, zarówno o prawidłowościach funkcjonowania człowieka w grupie społecznej $\mathrm{w}$ interakcji z innymi ludźmi, jak i w istniejących sytuacjach problemowych i trudnych ${ }^{71}$. Wsparcie społeczne można rozumieć w wieloraki sposób: 1) jako indywidualną percepcję sieci wspierającej, którą dysponuje jednostka, 2) jako wynik wspierającej wymiany społecznej, 3) jako charakterystyczny rodzaj wsparcia dostarczany jednostce ${ }^{72}$. Najczęściej termin ten bywa używany zamiennie z okre-

${ }^{69}$ Ibidem.

70 C.J. Dunst, C.M. Trivette, A.G. Deal, Family Functioning Style Scale, [w:] Enabling and empowering families: Principles and guidelines for practice, red. C.J. Dunst, C.M. Trivette, A.G. Deal, Brookline Books Cambridge 1988, s. 179-184.

${ }^{71}$ H. Sęk, Wsparcie społeczne - co zrobić, aby stało się pojęciem naukowym?, „Przegląd Psychologiczny" 1986, nr 3, s. 791.

72 S.D. Johnson, A framework for technology education curricula which emphasizes intellectual processes, “Journal of Technology Education,, 1992, nr 3(2), s. 29-40. 
śleniami tj.: stosunki, więzi, relacje i związki społeczne ${ }^{73}$. Podążając za Żółkowską, można przyjąć, że wsparcie społeczne ma charakter dynamiczny, zależne jest od aktualnej sytuacji człowieka, jak i od całego biegu jego życia. Należy tu wspomnieć, że wsparcie postrzegane jest subiektywnie i może być miarą tego, w jaki sposób środowisko społeczne reaguje na indywidualne potrzeby rodziców i osób z niepełnosprawnością intelektualną ${ }^{74}$. Wsparcie społeczne niesie wiele korzyści, spośród których jedną z ważniejszych jest otrzymywanie od innych potwierdzenia własnej skuteczności, które może odgrywać kluczową rolę w odbudowie wiary we własne siły w obliczu warunków słabnącej skuteczności rodzicielskiej.

Wsparcie społeczne może występować w formach dotrzymania towarzystwa, pomocy materialnej i wsparcia informacyjnego. Towarzystwo odnosi się do spędzania czasu razem z innymi, poczucia wzajemnej bliskości, wyrażania uznania oraz docenienia drugiej osoby. Pomoc materialna związana jest z zapewnieniem zasobów i rzeczywistej pomocy, natomiast wsparcie informacyjne wiąże się z dostępnością doradztwa i poradnictwa. Wsparcie i pomoc może być udzielana na różne sposoby, takie jak pomoc formalna (np. od psychologów i nauczycieli) oraz nieformalna (np. od znajomego lub innego rodzica).

Ważnym wskaźnikiem oceny przez rodziców korzyści z otrzymanego wsparcia czy też ich zdolności do korzystania z pomocy jest ocena satysfakcji z otrzymywanego wsparcia75. Zdaniem Hyun Song Shina na satysfakcję wpływają m.in. cechy osobiste rodzica dziecka niepełnosprawnego, a szczególnie te, dzięki którym rodzic daje sobie przyzwolenie na przyjęcie oferowanego wsparcia ${ }^{76}$. Według Sullivana na satysfakcję ze wsparcia mogą mieć też wpływ

73 A. Kacperczyk, Wsparcie społeczne w instytucjach opieki paliatywnej i hospicyjnej, Wydawnictwo Uniwersytetu Łódzkiego, Łódz 2006.

${ }^{74}$ T. Żółkowska, Normalizacja - niedokończona teoria pedagogiki specjalnej, „Niepełnosprawność" 2004, 2011, nr 5, s. 85-94.

75 J.Y. Shin, Social support for families of children with mental retardation: Comparison between Korea and the United States, "Mental Retardation" 2002, nr 40, s. 103-118.

76 Ibidem. 
różnice płciowe. Autor dostrzega je na płaszczyźnie oczekiwań rodzicielskich co do otrzymywanego wsparcia. W przeprowadzonych przez Sullivana badaniach okazało się bowiem, że kobiety częściej oczekiwały wsparcia emocjonalnego i miały większą potrzebę werbalizacji swoich przeżyć, natomiast ojcowie częściej podkreślali potrzebę pomocy materialnej i otrzymywania porad dotyczących rozwiązywania problemów ${ }^{77}$.

Interesujące wyniki na temat doznawania satysfakcji ze wsparcia przez matki niemowląt z zespołem Downa przeprowadzili Malka Margalit i współpracownicy ${ }^{78}$. Badania ujawniły, że oczekiwania matek dzieci niepełnosprawnych odnośnie do otrzymywanego wsparcia i bezpośredniej pomocy dla ich noworodków w dużej mierze zależały od postrzegania przez nie siły osobistej, ale także od poczucia spójności ich rodziny. Silne matki, które czuły się pewnie i miały wysokie poczucie własnej skuteczności, ale doświadczyły braku stabilności rodzinnej i sygnalizowały brak wsparcia społecznego, postrzegały personel wczesnej interwencji jako substytut rodziny, mówiąc: „Znalazłam nową rodzinę".

Matki o małej pewności siebie, ale czujące, że posiadają bardzo spójne rodziny nie szukały „nowej rodziny”, ale wyrażały zadowolenie z udziału w programie wspierania rodzin, mówiąc: „Pomagają mi uwierzyć, że mogę pomóc mojemu dziecku"79. Innym jeszcze czynnikiem wpływającym na satysfakcję ze wsparcia społecznego rodziców, zdaniem Victora Floriana i Tamar Krulik ${ }^{80}$, jest doświadczanie przez rodziców uczucia izolacji społecznej. Przeprowadzone przez nich badania ujawniły bowiem istnienie ujemnej korelacji pomiędzy dostępnością wsparcia społecznego i poczuciem samotności wśród matek.

77 A. Sullivan, op. cit.

78 T. Lackaye, M. Margalit, Comparisons of achievement, effort, and self-perceptions among students with learning disabilities and their peers from different achievement groups, “Journal of Learning Disabilities" 2006, nr 39, s. 432-446.

79 Ibidem.

${ }^{80}$ V. Florian, T. Krulik, Loneliness and social support of mothers of chronically ill children “Social Science Medicine” 1991, nr 32(11), s. 1291-1296. 


\section{Podsumowanie}

Podsumowując, rodzicielstwo jest ważnym czynnikiem dającym poczucie bezpieczeństwa młodemu człowiekowi i określającym jego status zarówno w systemie rodziny, jak i w społeczeństwie ${ }^{81}$. Pełniąc funkcję rodzicielską, rodzice mogą zaspokajać zarówno potrzeby własne np. uznanie, szacunek czy samorealizację, jak i potrzeby dzieci np. przekazywanie dzieciom wartości, wiedzy, dbanie o ich rozwój i przygotowywanie ich do funkcjonowania w społeczeństwie ${ }^{82}$. Jednocześnie przyjście na świat potomka z zespołem Downa jest sytuacją trudną, zdarzeniem nieoczekiwanym i często opisywanym w kategorii traumy ${ }^{83}$. W przypadku rodziców dzieci z niepełnosprawnością intelektualną nie można powiedzieć o wejściu lub przyjęciu roli rodzicielskiej, lecz bardziej trafnym stwierdzeniem jest mówienie o kilkuetapowym procesie przystosowania się do roli ${ }^{84}$.

Od 1980 r. naukowcy zmieniają spojrzenie na dziecko z zespołem Downa jako przyczynę psychopatologii rodziny, wprowadzając koncepcję niepełnosprawności dziecka jako czynnika stresującego $\mathrm{w}$ obrębie systemu rodzinnego ${ }^{85}$. Zgodnie $\mathrm{z}$ tą zmianą perspektywy czynnik stresujący $\mathrm{w}$ systemie rodzinnym, jakim jest niepełno-

${ }^{81}$ M. Ziemska, op. cit.

82 T. Rostowska, op. cit.

83 V. Będkowska-Heine, op. cit.; M. Kościelska, Trudne macierzyństwo...; H. Liberska, M. Matuszewska, op. cit.; A. Żyta, op. cit.

${ }^{84}$ V. Będkowska-Heine, op. cit.; R.N. Emde, C. Brown, op. cit.; M. Kościelska, Trudne macierzyństwo....

${ }^{85}$ M. Kościelska, Trudne macierzyństwo..., R.M. Hodapp, L.A. Ricci, Fathers of children with down's syndrome versus other types of intellectual disability: Perceptions, stress and involvement, "Journal of Intellectual Disability Research" 2003, nr 47, s. 273-284; M. Kulik, W. Otrębski, Sytuacja rodzinna z dzieckiem niepetnosprawnym w wyniku choroby genetycznej, [w]: Rodzina z dzieckiem niepetnosprawnym - możliwości i ograniczenia rozwoju, red. H. Liberska, Difin, Warszawa 2011, s. 75-89; H. Liberska, M. Matuszewska, Model rodziny z dzieckiem niepetnosprawnym, [w:] Rodzina z dzieckiem niepetnosprawnym - możliwości i ograniczenia rozwoju, red. H. Liberska, Difin, Warszawa 2011, s. 41-66. 
sprawność intelektualna dziecka, może prowadzić do negatywnych skutków rodzicielskich takich jak stres psychiczny, depresja, dolegliwości somatyczne oraz decyzje o separacji czy rozwodzie małżonków ${ }^{86}$. Jednocześnie niepełnosprawność intelektualna dziecka może również wzmacniać rodziców, nadając im sens i znaczenie swojego rodzicielstwa, co znajduje odzwierciedlenie w innych obszarach funkcjonowania rodziny, takich jak poziom spójności rodziny, pozytywna komunikacja między rodzicami niepełnosprawnego dziecka czy korzystanie ze wsparcia społecznego ${ }^{87}$.

Stres rodzicielski wydaje się wynikać z połączenia zwiększonych potrzeb opiekunczych dziecka z opóźnionym lub nieprawidłowym jego rozwojem, wraz z emocjonalnymi reakcjami rodziny na niepełnosprawność dziecka ${ }^{88}$. Sposób, w jaki rodzice radzą sobie z problemami wywołanymi przez niepełnosprawność intelektualną swojego potomka, przyczynia się do poprawy ich zdolności poznawczych, kontroli emocjonalnej i zachowania oraz do bardziej pozytywnej oceny swojego niepełnosprawnego intelektualnie dziecka ${ }^{89}$. Analogicznie, jeżeli rodzice będą w stanie obrać korzystny, zadaniowy styl radzenia sobie ze stresem, możemy wówczas mówić o korzystnej lub prawidłowej adaptacji do roli rodzicielskiej ${ }^{90}$.

86 W.N. Friedrich, W.L. Friedrich, Psychological assets of parents of handicapped and nonhandicapped children, "American Journal of Mental Deficiency" 1981, nr 85, s. 551-553.

87 V. Będkowska-Heine, op. cit.; J.S. Greenberg, M. Wyngaarden-Krauss, M. Mailick-Seltzer, R.R. Chou, J. Hong, op. cit.; R.M. Hodapp, Families of persons with down syndrome: New perspectives, findings, and research and service needs, "Developmental Disabilities Research Reviews" 2007, nr 13(3), s. 279-287, M. Kościelska, op. cit.; H. Liberska, M. Matuszewska, op. cit.; A. Żyta, Rodzeństwo osób z głębszą niepetnosprawnością intelektualna, Oficyna Wydawnicza „Impuls”, Kraków 2004.

88 E. Leinonen, M. Itälinna, T. Saloviita, op. cit.

${ }^{89}$ A.P. Turnbull, J.M. Patterson, S.K. Behr, D.L. Murphy, J.G. Marquis, M.J. Blue-Banning, op. cit.

${ }^{90}$ B.H. Abery, op. cit.; T. Lackaye, M. Margalit, op. cit.; M. Van Riper, A change of plans: the birth of a child with down syndrome doesn't have to be a negative experience, “American Journal of Nursing" 2003, nr 103, s. 71-74. 
Ogólnie mówiąc, proces adaptacji do roli rodzica dziecka z zespołem Downa jest trudny, wieloetapowy i stresogenny zarówno dla matki, jak i dla ojca. Ciągłe wyzwania jakie niesie ze sobą walka ze stresem rodzicielskim u matek i ojców dziecka z zespołem Downa zwiększa znaczenie dostępnych możliwości różnych form wsparcia społecznego. Korzystanie ze wsparcia społecznego ma olbrzymie znaczenie dla procesu adaptacji do roli rodzica dziecka z zespołem Downa, ponieważ rozwija poczucie, że jest się pod opieką, że należy się do społeczności z podobnymi problemami oraz że jest się osobą wysłuchaną, zrozumianą i że można być wsparciem również dla innych osób, które mają podobne doświadczenia ${ }^{91}$.

\section{Bibliografia}

Abery B.H., Focus on Exceptional Children, „Family Adjustment and Adaptation with Children with Down Syndrome" 2006, nr 38(6).

Abidin R., Parenting stress index manual, "Psychological Assessment Resources” 1995.

Atkinson L., Bowman T., Minton H.L., Scott B.S., Psychological distress of parents of infants with down syndrome, "American Journal on Mental Retardation" 1997, nr 102(2).

Beckman-Bell P., To pics in Early Childhood Special Education, "Child - related stress in families of handicapped children" 1981, nr 1(3).

Będkowska-Heine V., Tworzenie roli matki dziecka niepetnosprawnego, [w:] Wybrane zagadnienia psychopatologii rozwoju dzieci i młodzieży, red. S. Michilewicz, Oficyna Wydawnicza „Impuls”, Kraków 2003.

Będkowska-Heine V., Wptyw przewlekłej choroby dziecka na funkcjonowanie w roli ojca, [w:] Dziecko chore. Zagadnienia biopsychiczne i pedagogiczne, red. B. Cytowska, B. Winczura, Oficyna Wydawnicza „Impuls”, Kraków 2007.

Blacher J., Neece C.L., Paczkowski E., Families and intellectual disability. "Current Opinion in Psychiatry" 2005, nr 18(5).

Cencini A., Manenti A., Psychologia a formacja, Wydawnictwo WAM, Kraków 2002.

Cummings S., Bayley H., Rie H., Effects of the child's deficiency on the mother: A study of mentally retarded, chronically ill, and neurotic children, "American Journal of Orthopsychiatry" 1966, nr 36.

${ }^{91}$ C.J. Dunst, C.M. Trivette, A.G. Deal, op. cit. 
Cognitive doping, families and disability, red. A.P. Turnbull, J.M. Patterson, S.K. Behr, D.L. Murphy, J.G. Marquis, M.J. Blue-Banning, Paul H. Brookes Publishing Co., Baltimore 1993.

Dunst C.J., Trivette C.M., Deal A.G., Family Functioning Style Scale, [w:] Enabling and empowering families: Principles and guidelines for practice, red. C.J. Dunst, C.M. Trivette, Deal A.G., MA: Brookline Books, Cambridge 1988.

Emde R.N., Brown C., Adaptation to the birth of a Down's syndrome infant: Grieving and maternal attachment, "Journal of the American Academy of Child Psychiatry" 1978, nr 17.

Florian V., Krulik T., Loneliness and social support of mothers of chronically ill children, "Social Science Medicine" 1991, nr 32 (11).

Folkman S., Lazarus R.S., Coping as a mediator of emotion, "Journal of Personality and Social Psychology" 1988, nr 54.

Folkman S., Moskowitz J.T., Coping: pitfalls and promise, "Annual Review of Psychology" 2004, nr 55.

Friedrich W.N., Friedrich W.L., Psychological assets of parents of handicapped and nonhandicapped children, "American Journal of Mental Deficiency" 1981, nr 85, s. 551-553.

Greenberg J.S., Wyngaarden-Krauss M., Mailick-Seltzer M., Chou R., Hong J., The effect of quality of the relationship between mothers and adult children with schizophrenia, autism, or Down syndrome on maternal well-being: the mediating role of optimism, "American Journal of Orthopsychiatry" 2004, nr 74(1).

Hall S., Bobrow M., Marteau T.M., Psychological consequences for parents of false negative results on prenatal screening for Down's syndrome: Retrospective interview stu$d y$, "British Medical Journal" 2000, nr 320.

Harwas-Napierała B., Specyfika komunikacji interpersonalnej w rodzinie ujmowanej jako system, [w:] Psychologia rodziny, red. I. Janicka, H. Liberska, Wydawnictwo Naukowe PWN, Warszawa 2014.

Hodapp R.M., Families of persons with down syndrome: New perspectives, findings, and research and service needs, "Developmental Disabilities Research Reviews", nr 13(3).

Hodapp R.M., Ricci L.A., Fathers of children with down's syndrome versus other types of intellectual disability: Perceptions, stress and involvement, "Journal of Intellectual Disability Research" 2003, nr 47.

Johnson S.D., A framework for technology education curricula which emphasizes intellectual processes, "Journal of Technology Education 1992, nr 3(2).

Kacperczyk A., Wsparcie społeczne w instytucjach opieki paliatywnej i hospicyjnej, Wydawnictwo Uniwersytetu Łódzkiego, Łódź 2006.

Keller D., Honig A.S., Maternal and Paternal Stress in Families with School-Aged Children with Disabilities, "American Journal of Orthopsychiatry" 2004, nr 74(3).

Kościelska M., Oblicza upośledzenia, Wydawnictwo Naukowe PWN, Warszawa 1995. 
Kościelska M., Trudne macierzyństwo, Wydawnictwo Szkolne i Pedagogiczne, Warszawa 1998.

Kulik, M., Otrębski W., Sytuacja rodzinna z dzieckiem niepetnosprawnym w wyniku choroby genetycznej, [w:] Rodzina z dzieckiem niepetnosprawnym - możliwości i ograniczenia rozwoju, red. H. Liberska, Difin, Warszawa 2011.

Lackaye T., Margalit M., Comparisons of achievement, effort, and self-perceptions among students with learning disabilities and their peers from different achievement groups, “Journal of Learning Disabilities" 2006, nr 39.

Lam L., Mackenzie A.E., Coping with a child with Down syndrome: The experience of mothers in Hong Kong, "Qualitative Health Research" 2002, nr 12.

Leinonen E., Itälinna M., Saloviita T., Explaining the parental stress of fathers and mothers caring for a child with intellectual disability: A Double ABCX model, "Journal of Intellectual Disability Research" 2003, nr 47.

Lent R.W., Toward a Unifying Theoretical and Practical Perspective on Well-Being and Psychosocial Adjustment, "Journal of Counseling Psychology" 2004, nr 51(4).

Liberska H., Rodzina z dzieckiem niepetnosprawnym - możliwości i ograniczenia rozwoju, Wydawnictwo Difin, Warszawa 2011.

Liberska H., Matuszewska M., Model rodziny z dzieckiem niepetnosprawnym, [w:] Rodzina z dzieckiem niepetnosprawnym - możliwości i ograniczenia rozwoju, red. H. Liberska, Difin, Warszawa 2011.

Łoś M., "Role społeczne" w nowej roli, [w:] Małe struktury społeczne, red. J. Machaj, Wydawnictwo UMCS, Lublin 1999.

Plopa M., Więzi w matżenstwie i rodziny. Metody Badań, Oficyna Wydawnicza „Impuls", Kraków 2006.

Peterson G.W., Hennon C.B., Conceptualizing prenatal stress with family stress theory, [w:] Families and change, red. P.C. McKenry, S.J. Price; Thousand Oak, California 2005.

Richardson G.E., The metatheory of resilience and resiliency, "Journal of Clinical Psychology" 2002, nr 58.

Roach M., Orsmond G.I., Barratt M.S., Mothers and fathers of children with Down syndrome: Parental stress and involvement in childcare, "American Journal on Mental Retardation" 1999, nr 104.

Rostowska T., Małżeństwo, rodzina, praca a jakość życia, Oficyna Wydawnicza „Impuls", Kraków 2009.

Sęk H., Wsparcie społeczne - co zrobić, aby stało się pojęciem naukowym?, "Przegląd Psychologicziny" 1986, nr 3.

Shin J.Y., Social support for families of children with mental retardation: Comparison between Korea and the United States, "Mental Retardation" 2002, nr 40.

Siklos S., Kerns K.A., Assessing need for social support in parents of children with autism and Down syndrome, "Journal of Autism and Developmental Disorders" 2006, nr 36(7). 
Skotko B., Mothers of children with down syndrome reflect on their postnatal support, "Pediatrics" 2005, nr 115.

Sullivan A., Gender differences in coping strategies of parents of children with Down syndrome, "Down Syndrome Researches and Practice" 2002, nr 8(2).

Van Riper M., Maternal perceptions of family-provider relationships and well-being in families of children with down syndrome, "Research in Nursing and Health" 1999, nr 22.

Van Riper M., A change of plans: the birth of a child with down syndrome doesn't have to be a negative experience, "American Journal of Nursing" 2003, nr 103.

Wayne D.O.M., Krishnagiri S., Parents' leisure: The impact of raising a child with down syndrome, "Occupational Therapy International" 2005, nr 12(3).

Zahn-Waxler C., Duggal S., Gruber R., Parental psychopathology, [w:] Handbook of parenting 2, 3, red. M.H. Bornstein, Mahwah, Lawrence Erlbaum Associates, Mahwah 2002.

Ziemska M., Postawy rodzicielskie, Wiedza Powszechna, Warszawa 1973.

Ziemska M., Rodzina a osobowość, Wiedza Powszechna, Warszawa 1979.

Żółkowska T., Normalizacja - niedokończona teoria pedagogiki specjalnej, „Niepełnosprawność" 2004, 2011, nr 5.

Żyta A., Rodzeństwo osób z głębszą niepetnosprawnością intelektualną, Oficyna Wydawnicza „Impuls”, Kraków 2004. 